\title{
Tingkat Kepuasan Orangtua Pasien di Pediatri Rawat Jalan Departemen IImu Kesehatan Anak Rumah Sakit Umum Pusat Dr. Cipto Mangunkusumo Jakarta
}

\author{
James L. Alvin Sinaga, Soepardi Soedibyo, Harry S. Purwanto, Aman B. Pulungan
}

Latar belakang. Sejak tahun 2000 hingga kuartal I tahun 2005 angka kunjungan pasien rawat jalan mengalami penurunan secara gradual di Unit Rawat Jalan Departemen Ilmu Kesehatan Anak Rumah Sakit Umum Pusat Dr. Cipto Mangunkusumo (URJ Departemen IKA RSUP CM) Jakarta. Kecenderungan penurunan angka kunjungan pasien merupakan indikator bagi pengelola untuk meninjau kembali strategi pelayanan di Pediatri Rawat Jalan.

Tujuan Penelitian. Meneliti tingkat kepuasan orangtua pasien yang membawa anaknya berobat jalan di URJ Departemen IKA RSCM.

Metoda penelitian. Studi survai deskriptif dengan metode potong lintang (cross sectional) dilakukan di URJ Departemen IKA RSCM dalam kurun waktu Agustus Nopember 2005. Pengumpulan data primer menggunakan kuesioner yang terstruktur berisi 30 pertanyaan.

Hasil penelitian. Dari 144 orang tua pasien, enam puluh dua persen orangtua pasien merasa puas terhadap kualitas pelayanan, skor kepuasan total terhadap dimensi kualitas pelayanan 3,55 (puas). Bukti fisik (tangibility) memberi skor kepuasan tertinggi sedangkan kehandalan pelayanan (reliability) memberi skor kepuasan terendah bagi orangtua pasien.

Kesimpulan. Kualitas pelayanan di URJ Departemen IKA RSCM memuaskan (skor $3,55)$ dan persentase orangtua pasien yang puas $62 \%$.

Kata kunci: kepuasan pelanggan, pediatri rawat jalan, RS Dr. Cipto Mangunkusumo

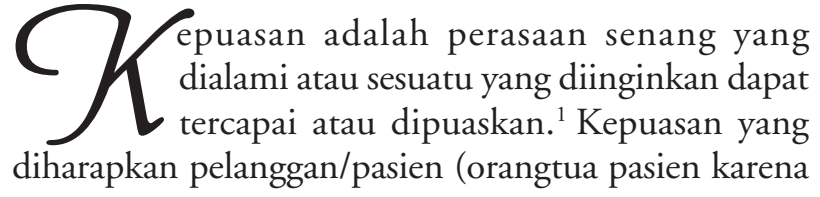

\footnotetext{
Alamat korespondensi:

Dr. Soepardi Soedibyo, SpA(K). Divisi Nutrisi dan metabolik. Departemen Ilmu Kesehatan Anak FKUI-RSCM. Jl. Salemba no.6, Jakarta 10430. Telepon: 021-3915179. Fax: 021-390 7743.

Dr. James L. Alvin Sinaga PPDS IKA RSCM
}

anak belum dapat membuat keputusan bagi dirinya) terhadap pelayanan kesehatan adalah perhatian (care), kenyamanan (comfort), dan kesembuhan (cure). ${ }^{2}$ Bila kepuasan yang diharapkan tidak dapat dipenuhi maka pelanggan akan beralih ke sarana pelayanan yang lain, tetapi bila kepuasan pelanggan dapat dipenuhi maka pelanggan akan tetap setia menggunakan jasa pelayanan, menceriterakan hal yang baik tentang pelayanan dan akan patuh terhadap petunjuk yang diberikan. ${ }^{3}$ Bila harapan semakin tinggi dan dapat dipenuhi maka tingkat kepuasan semakin tinggi, bila 
harapan sedikit maka tingkat kepuasannya semakin rendah. ${ }^{4}$

Isu kepuasan perlu mendapat perhatian yang utama di URJ (unit rawat jalan) melebihi unit lain di rumah sakit karena URJ merupakan pintu gerbang rumah sakit, citra rumah sakit, jumlah kunjungan terbesar pasien RS, pusat rujukan bagi institusi kesehatan lainnya, pusat keuntungan dan pusat pembiayaan (profit centre and cost centre), ${ }^{5}$ Perhatian terhadap kepuasan pasien/orangtua pasien di unit rawat jalan anak menjadi begitu penting sebab 70\% layanan pediatri berlangsung di URJ dan kesalahan dalam pengobatan lebih sering terjadi. ${ }^{6,7}$ Menurut American Academy of Family Physician (AAFP) ${ }^{8}$ $17,5 \%$ kesalahan yang terjadi pada pengobatan anak berada pada usia kurang dari 14 tahun dan 5\% terjadi pada bagian pendaftaran. Institute of Medicine ${ }^{9}$ melaporkan bahwa tingkat kesalahan dalam pengobatan 3 kali lebih sering pada anak dibandingkan pada orang dewasa.

Bila harapan orangtua pasien tidak dapat dipuaskan maka mereka akan kecewa dan beralih ke sarana kesehatan lain yang mereka harapkan dapat memberikan kepuasan. Menurut Jerald Young (dikutip dari Leebov) ${ }^{10}$ terdapat empat alasan mengapa pasien yang tidak puas beralih ke pusat pelayanan yang lain 54\% karena merasa tidak nyaman, 23\% karena waktu pelayanan lama, dan $23 \%$ karena kualitas pelayanan yang buruk. Untuk memberikan kepuasan kepada pelanggan maka pihak penyedia layanan kesehatan (health provider) harus mengenal pelanggannya.

Sejak tahun 2001 pemerintah merubah status badan hukum RSCM dari badan layanan umum (BLU) menjadi perusahaan jawatan (Perjan) dengan harapan RSCM mempunyai otonomi yang luas tanpa meninggalkan fungsi sosialnya karena semakin berkembangnya paradigma sehat. ${ }^{11}$ Dengan perubahan badan hukum ini RSCM diharapkan dapat meningkatkan kualitas pelayanan yang berorientasi kepada kepuasan pelanggan.

Menurut data rekam medik Departemen IKA RSCM jumlah kunjungan pasien anak di URJ mengalami penurunan sejak tahun 2000 hingga kuartal I tahun 2005 (lihat Tabel 1). Besarnya prosentase penurunan jumlah kunjungan setiap tahun masing-masing 13\%, 8\%, $8 \%$, $12 \%$ dan $4 \%$. Bila kecenderungan penurunan ini tidak diantisipasi dan tidak disusun suatu strategi baru untuk mengatasinya maka kerugian finansial akan berlanjut dan kesinambungan peserta program pendidikan dokter spesialis (PPDS) di Departemen IKA RSCM juga akan terancam. Beragam faktor dapat menyebabkan keadaan seperti ini, salah satunya adalah ketidakpuasan pasien/ orangtua pasien.

Tabel 1. Jumlah kunjungan pasien URJ Departemen IKA RSUPN CM tahun 2000 Kuartal I 2005

\begin{tabular}{|c|c|c|c|c|c|c|c|}
\hline No. & Poliklinik & 2000 & 2001 & 2002 & 2003 & 2004 & Kw1 2005 \\
\hline 1. & Alergi - imunologi & 1.224 & 1.067 & 881 & 689 & 563 & 202 \\
\hline 2. & Endokrinologi & 1.111 & 882 & 959 & 860 & 767 & 297 \\
\hline 3. & Gastroenterelogi & 817 & 637 & 657 & 612 & 667 & 244 \\
\hline 4. & Gizi & 799 & 864 & 795 & 812 & 547 & 208 \\
\hline 5. & Hematologi & 3.429 & 3.668 & 3.377 & 3.355 & 3.271 & 1.119 \\
\hline 6. & Hepatologi & 214 & 270 & 284 & 319 & 322 & 151 \\
\hline 7. & Imunisasi & 1.784 & 1.355 & 1.111 & 69 & 367 & 88 \\
\hline 8. & Kardiologi & 2.684 & 2.510 & 2.307 & 2.123 & 1.613 & 491 \\
\hline 9. & Nefrologi & 2.481 & 2.511 & 2.331 & 2.171 & 1.985 & 745 \\
\hline 10 & Pulmonologi & 6.872 & 4.865 & 4.001 & 2.933 & 2.027 & 628 \\
\hline 11. & Perinatologi & 411 & 295 & 180 & 196 & 160 & 30 \\
\hline 12. & Psikiatri anak & 515 & 359 & 399 & 376 & 239 & 106 \\
\hline 13. & Umum & 17.355 & 13.409 & 11.958 & 11.222 & 8.287 & 2.383 \\
\hline 14. & Neurologi & 4.421 & 4.199 & 3.586 & 3.442 & 3.686 & 845 \\
\hline 15. & Thalasemia & 6.961 & 7.244 & 7.215 & 7.381 & 7.387 & 2.662 \\
\hline 16. & \multicolumn{2}{|c|}{ Tumbuh kembang anak 263} & 293 & 389 & 440 & 431 & 130 \\
\hline & $\mathrm{J} \mathrm{u} \mathrm{m} \mathrm{l} \mathrm{a} \mathrm{h}$ & 51.338 & 44.378 & 40.430 & 37.003 & 32.319 & 10.332 \\
\hline
\end{tabular}

* tahun 2005 kwartal 1 
Tujuan penelitian ini adalah untuk mengetahui tingkat kepusasan orangtua pasien terhadap dimensi kualitas pelayanan.

\section{Metoda}

Penelitian merupakan studi survai deskriptif dengan metoda pengumpulan data potong lintang (cross sectional), dilakukan di URJ Departemen IKA RSCM pada bulan Agustus 2005-Nopember 2005. Data yang diperoleh adalah data primer dengan menggunakan kuesioner sebagai instrumen penelitian. Subyek penelitian ini melibatkan 144 orangtua pasien yang membawa anaknya berobat jalan dan memenuhi kriteria. Jumlah subjek diambil dari setiap poliklinik berdasarkan alokasi proporsional. Pengambilan subjek dilakukan secara consecutive sampling sesuai data awal. ${ }^{12,13}$

Kuesioner mengacu pada konsep kepuasan pelanggan karya Parasuraman, dkk yang berjudul SERVEQUAL (service quality) dan telah diadopsi secara luas diseluruh dunia untuk mengukur tingkat kepuasan pelanggan/pasien di rumah sakit. ${ }^{14-15}$ Kuesioner terdiri dari 30 pertanyaan terstruktur yang mewakili lima dimensi kualitas pelayanan seperti bukti fisik (tangibility), kehandalan (reliability), ketanggapan (responsiveness), jaminan kepastian (assurance) dan perhatian (empathy) yang telah lebih dulu diuji kesahihan dan kehandalannya. Pertanyaan pada kuesioner terdiri dari lima jawaban pilihan yang diberi bobot 1 sampai 5 skala Likert. Skala 1 (sangat tidak memuaskan), 2 (tidak memuaskan), 3 (biasa-biasa), 4 (puas) dan 5 (sangat puas).

Penilaian terhadap tingkat kepuasan total dilakukan berdasarkan sistim skoring dengan cara menjumlahkan seluruh nilai dari 30 pertanyaan dibagi 30. Tingkat kepuasan orangtua pasien dibagi atas 5 kelas yaitu sangat tidak puas bila nilai skornya 1-1,79, tidak puas skor 1,80-2,59, biasa-biasa skor 2,60-3,39, puas skor 3,40-4,19 dan sangat puas bila skor 4,205,00. Data diolah menggunakan program SPSS 11.00. Analisis data dilakukan secara deskriptif.

\section{Hasil penelitian dan pembahasan}

Berdasarkan Tabel 2 diperoleh, 90 (62\%) orangtua pasien merasa puas dan sangat puas, 47 (32\%) biasabiasa, 7 (4\%) tidak puas dan tidak seorangpun merasa sangat tidak puas terhadap kualitas pelayanan di URJ Departemen IKA RSCM. Tingkat kepuasan total orang tua pasien pada penelitian ini lebih tinggi bila dibandingkan dengan tingkat kepuasan total orangtua pasien yang diperoleh peneliti lain. Zaihan (2003) di unit rawat jalan RSU Palembang memperoleh angka sebesar 54\%, Madiar (2003) di unit rawat jalan anak RSIA Hermina Depok sebesar 43\%, Sakti di poliklinik anak RSUD Muara Bungo sebesar 28\% dan Sumampow di poliklinik anak di RSAL Dr. Mintoharjo Jakarta dengan tingkat kepuasan yang lebih rendah yaitu $27,3 \% .{ }^{16-19}$

Dimensi kualitas pelayanan yang memberikan skor tingkat kepuasan tertinggi hingga terendah adalah bukti fisik (tangibility), daya tanggap (responsiveness), perhatian (empathy), jaminan kepastian (assurance) dan kehandalan (reliability). Dari seluruh subvariabel yang dinilai tidak ada yang sangat memuaskan, tiga subvariabel memperoleh skor tertinggi yaitu 1) penampilan karyawan dengan pakaian seragam yang rapi dan bersih, 2) kelengkapan dan kecanggihan peralatan medis, 3) kemampuan dan ketanggapan dokter dalam meyelesaikan masalah sedangkan tujuh subvariabel yang memperoleh skor biasa (artinya tidak memuaskan, tidak ada kelebihannya) yaitu waktu tunggu (skor 2,9), ketepatan waktu pelayanan dan jam praktek dokter (skor 3,1), kebersihan dan kenyamanan toilet/wc (skor 3.1), perhatian khusus yang diberikan individu terhadap karyawan (skor 3,2), tatacara penerimaan pasien yang cepat dan tepat (skor 3,3), proses administrasi cepat dan tepat dan biaya pengobatan/tarif yang dapat dijangkau (skor 3,3).

Skor kepuasan rata-rata orangtua pasien terhadap dimensi kualitas pelayanan adalah 3,55 dengan SD 0,74 artinya orangtua pasien merasa puas terhadap dimensi pelayanan di URJ Departemen IKA RSCM.

Tabel 2. Sebaran tingkat kepuasan total orangtua pasien

\begin{tabular}{lc}
\hline Kepuasan & Jumlah $(\%)$ \\
\hline Sangat tidak puas & $0(0)$ \\
Tidak puas & $7(4)$ \\
Biasa-biasa & $47(32)$ \\
Puas & $71(49)$ \\
Sangat puas & $19(13)$ \\
\hline Total & $144(100)$ \\
\hline
\end{tabular}


Sari Pediatri, Vol. 8, No. 2, September 2006

Tabel 3. Tingkat kepuasan berdasarkan dimensi kualitas pelayanan

\begin{tabular}{|c|c|c|c|c|}
\hline No & Variabel & $\begin{array}{l}\text { Nilai } \\
\text { rerata }\end{array}$ & SD & $\begin{array}{l}\text { Tingkat } \\
\text { kepuasan }\end{array}$ \\
\hline \multirow[t]{8}{*}{1.} & Bukti Fisik (tangibility) & 3,67 & & \\
\hline & 1. Penampilan karyawan dengan pakaian seragam yang rapi dan bersih & 4,0 & 0,8 & Puas \\
\hline & 2. Kebersihan, kenyamanan dan ketenangan ruang tunggu & 3,6 & 0,9 & Puas \\
\hline & 3. Kebersihan, kerapian dan kenyamanan kamar periksa & 3,7 & 0,8 & Puas \\
\hline & 4. Kelengkapan dan kecanggihan peralatan medis & 4,0 & 0,8 & Puas \\
\hline & 5. Kelengkapan, kerapian, dan kebersihan alat-alat yang dipakai & 3,8 & 0,8 & Puas \\
\hline & 6. Keberadaan dan penempatan papan petunjuk yang jelas & 3,5 & 0,8 & Puas \\
\hline & 7. Kebersihan dan kenyamanan toilet/wc & 3,1 & 1,0 & Biasa-biasa \\
\hline \multirow[t]{7}{*}{2.} & Kehandalan Pelayanan (reliability) & 3,38 & & \\
\hline & 8. Kemampuan memberikan informasi yang jelas & 3,6 & 1,0 & Puas \\
\hline & 9. Tatacara penerimaan pasien yang cepat dan tepat & 3,3 & 1,1 & Biasa-biasa \\
\hline & 10. Proses administrasi cepat dan tepat. & 3,3 & 1,1 & Biasa-biasa \\
\hline & 11. Ketepatan waktu pelayanan dan jam praktek dokter & 3,1 & 1,1 & Biasa-biasa \\
\hline & 12. Ketepatan, kecepatan pelayanan pemeriksaan dan pengobatan & 3,5 & 1,0 & Puas \\
\hline & 13. Cara penyimpanan arsip/ dokumen medis yang rapi dan baik & 3,5 & 1,0 & Puas \\
\hline \multirow[t]{5}{*}{3.} & Daya tanggap (responsiveness) & 3,62 & & \\
\hline & 14. Kemampuan dan ketanggapan dokter dalam menyelesaikan keluahan pasien & 4,0 & 0,9 & Puas \\
\hline & 15. Kemampuan dan ketanggapan perawat dalam menyelesaikan keluhan pasien & 3,5 & 0,9 & Puas \\
\hline & 16. Tindakan cepat pada saat pasien membutuhkan pertolongan & 3,5 & 0,9 & Puas \\
\hline & 17. Kesiapan karyawan untuk membantu setiap saat & 3,5 & 0,8 & Puas \\
\hline \multirow[t]{9}{*}{4.} & Jaminan kepastian (assurance) & 3,50 & & \\
\hline & 18. Pelayanan yang sopan dan ramah & 3,6 & 0,8 & Puas \\
\hline & 19. Ketrampilan dan pengetahuan dokter menetapkan diagnosis penyakit. & 3,9 & 0,9 & Puas \\
\hline & 20. Ketrampilan para perawat dan petugas lainnya dalam bekerja & 3,5 & 0,8 & Puas \\
\hline & 21. Jaminan keamanan dan kepercayaan terhadap pelayanan. & 3,5 & 0,9 & Puas \\
\hline & 22. Waktu tunggu & 2,9 & 1,1 & Biasa-biasa \\
\hline & 23. Kemampuan memegang rahasia pasien dan penyakitnya & 3,8 & 0,9 & Puas \\
\hline & 24. Biaya pengobatan (tarif) yang dapat dijangkau & 3,3 & 1,1 & Biasa-biasa \\
\hline & 25. Kehati-hatian dan ketenangan perilaku petugas & 3,6 & 0,8 & Puas \\
\hline \multirow[t]{6}{*}{5.} & Perhatian (empathy) & 3,52 & & \\
\hline & 26. Perhatian yang diberikan secara khusus kepada setiap pasien & 3,6 & 0,9 & Puas \\
\hline & 27. Kesediaan dokter untuk mendengarkan dan menanggapi keluhan pasien & 3,8 & 0,8 & Puas \\
\hline & 28. Perhatian terhadap keluhan dan kekhawatiran pasien serta keluarganya & 3,5 & 0,8 & Puas \\
\hline & 29. Perhatian khusus terhadap individu yang diberikan karyawan & 3,2 & 0,9 & Biasa-biasa \\
\hline & 30. Pelayanan kepada semua pasien tanpa memandang status sosial dan lain-lain & 3,5 & 1,1 & Puas \\
\hline
\end{tabular}

Srenivas \& Prasad $^{2}$ menyebutkan bawa kepuasan yang diharapkan oleh pasien/orangtua pasien adalah perhatian, kenyamanan dan kesembuhan. Tingginya tingkat kepuasan orangtua pasien terhadap bukti fisik seperti penampilan karyawan dengan pakaian seragam yang rapi dan bersih kelengkapan dan kecanggihan peralatan medis dipengaruhi oleh lima elemen kunci kepuasan pelanggan yaitu harapan (expectation), penampilan (perfomance), pembanding (comparison), ada tidaknya kesesuasian/ketidaksesuaian (confirmation/ disconfirmation) dan perbedaan (discrepancy). ${ }^{2}$ Menurut asumsi peneliti tingginya tingkat kepuasan terhadap bukti fisik tersebut disebabkan penampilan yang mereka lihat dan rasakan melebihi apa yang mereka harapkan, 
mungkin mereka tidak mepunyai pengalaman mengobati anaknya ke institusi lain yang melebihi URJ Departemen IKA RSCM sebagai pembanding, rendahnya kinerja dimensi kualitas pelayanan yang lain, perbaikan sarana fisik mendahului penelitian ini.

Dari tujuh subvariabel yang memperoleh skor kepuasan biasa dapat dibagi atas 3 kelompok yaitu kebersihan dan kenyamanan toilet, waktu tunggu yang lama (skor 2,90) yang tak dapat dipisahkan dari ketepatan waktu pelayanan dan jam praktek dokter (skor $3,1)$, tatacara penerimaan pasien yang cepat dan tepat (skor 3,3), proses administrasi cepat dan tepat $(3,3)$, biaya pengobatan (tarif) yang dapat dijangkau 4) perhatian khusus yang diberikan kepada pelanggan. Kebersihan dan kenyamanan toilet belum memuaskan bagi orangtua pasien karena jumlah toilet yang tersedia hanya satu unit untuk semua pasien dan keluarganya sehingga waktu tunggu pasien sangat lama dan menyusahkan bagi keluarga pasien, kemampuan petugas untuk membersihkannya relatif kurang.

Berapa lama waktu yang dibutuhkan untuk menunggu khususnya di rumah sakit pemerintah tidak ada yang berani menjamin. Menunggu sangat membosankan terutama bila tidak ada jaminan yang diberikan. Waktu tunggu yang lama merupakan faktor ketidakpuasan kedua setelah ketidakbersahabatan dan ketidakramahan petugas. Waktu tunggu yang lama perlu mendapat perhatian dan prioritas utama karena penyakit dapat mengalami perburukan, keluarga yang menunggu di rumah menjadi cemas, inefisiensi waktu pelayanan, hilangnya jam kerja yang seharusnya masih dapat digunakan orangtua pasien. ${ }^{20}$

Lama waktu tunggu yang ideal di unit rawat jalan anak sangat bervariasi. Pada penelitian yang dilakukan Fernandes ${ }^{21}$ di IGD 90\% masih betah menunggu sampai satu jam dan $60 \%$ dari pasien yang pulang tanpa pemeriksaan disebabkan lamanya waktu tunggu. Cupit $^{22}$ melaporkan bahwa $55 \%$ pasien rawat jalan menjalani pemeriksaan setelah menunggu 1 jam. Menurut penelitian Bedi, $\mathrm{dkk}^{23} 54 \%$ pasien dewasa di $\mathrm{RS}$ rujukan sekunder mengharapkan waktu tunggu 3045 menit dan $40 \%$ pasien dewasa di rumah sakit rujukan tersier mengharapkan waktu tunggu 20-30 menit tetapi pada kenyataannya $47 \%$ pasien di RS rujukan sekunder dan $72 \%$ pasien di rumah sakit rujukan tersier menghabiskan waktu $>1$ jam. The Institute of Medicine ${ }^{24}$ menyarankan supaya paling sedikit $90 \%$ pasien yang sudah terjadwal hendaknya diperiksa dalam waktu 30 menit. Di URJ setiap pasien menghabiskan waktunya untuk menunggu rata-rata 99 menit. ${ }^{25}$

Waktu tunggu yang lama di URJ Departemen IKA RSCM disebabkan jam pelayanan dan jam praktek dokter terkesan lama, dimulai jam 9.30-10.00 dua jam setelah loket pendaftaran dimulai, tata cara penerimaan pasien terkesan lambat dan kurang tepat, proses administrasi terkesan lambat dan kurang tepat. Blender menyatakan bahwa waktu tunggu pelayanan berbanding lurus dengan kemauan pasien melakukan kunjungan ulang. Bila kepuasan pasien terhadap waktu kunjungan ulang semakin baik maka kunjungan ulang akan semakin meningkat dan bila kepuasan makin buruk maka kunjungan ulang akan semakin berkurang. ${ }^{26}$

Biaya/tarif pemeriksaan terkesan tidak memuaskan (skor 3,3 biasa) artinya masih dianggap mahal pada besaran Rp 40.000 bagi pasien baru dan Rp 25.000 bagi pasien lama. Menurut penilaian peneliti besaran tarif tersebut tidak perlu diturunkan karena besaran harga tersebut relatif murah bila dibandingkan dengan pelayanan subspesialistik di rumah sakit swasta lain dan kualitas pelayanan kita relatif memuaskan bagi orangtua pasien. Secara keseluruhan dimensi perhatian (empathy) memberi kepuasan bagi orangtua pasien kecuali perhatian khusus terhadap individu yang diberikan karyawan. Perhatian mempunyai korelasi yang langsung terhadap kepuasan pasien/orangtua pasien.

\section{Kesimpulan dan saran}

Dari hasil penelitian ini dapat disimpulkan bahwa distribusi orangtua pasien yang puas terhadap pelayanan sebesar $62 \%$ dan tingkat kepuasan total orangtua pasien terhadap dimensi pelayanan skornya 3,55 (puas). Dimensi bukti fisik (tangibility) memberikan kepuasan tertinggi sedangkan kehandalan pelayanan (reliability) memberikan kepuasan terendah. Waktu tunggu memberi skor kepuasan terendah bagi orangtua pasien. Perbaikan perlu dilakukan untuk meningkatkan kepuasan orangtua pasien. Hal-hal yang perlu dan segera dilakukan adalah mempersingkat waktu tunggu dengan cara mempercepat jam praktek dokter, tata cara penerimaan pasien dan proses administrasi disederhanakan dengan menggunakan aplikasi sistem informasi manajemem rumah sakit terpadu sehingga pelayanan cepat dan tepat. Selain hal 
diatas perlu ditingkatkan kebersihan dan kenyamanan toilet/wc, perlu diadakan pelatihan kepuasan pelanggan bagi seluruh staf dan kariawan.

\section{Daftar Pustaka}

1. Crowther J, Kavanagh K, Ashby M. Oxford Advanced earnerDictionary, edisi ke-5. Lonson: Oxford University Press 1995. h.1042.

2. Srenivas T, Prasad G. Patient satisfaction - A comparative study. J Acad Hosp Adm 2003;5(2):9-10.

3. Baron-Epel O, Dushenat M, Freidman N. Evaluation of the consumer model : relationship between patients expectation, perceptions and satisfaction care. International Journal for Quality in Healthcare 2001:13:317-23.

4. Thompson DA, Yarnold PR. Relating patient satisfaction to waitingtime perception and expectation : the disconfirmation paradigm. Acad Emerge Med. 1995 Des 2:1057-62.

5. Riyadi S. Pelatihan manajemen rumah sakit. Pokja Kajian Pelayanan Kesehatan. Penelitian Kesehatan Universitas Indonesia. Administrasi Rumah sakit. Jakarta, 1999.

6. Bates D, Cullen D, Laird N. Incidence of adverse and potential adverse drug events: implication for prevention. JAMA 1997;274:29-34.

7. Classen D, Pestotnik S, Evans R. Adverse drug events in hospitalized patients. JAMA 1997;277:301-6.

8. Dovey S, Philip R, Green L. Medical error affecting vulnerable primary care patient in six countries:A report of LINNAEUS collaboration. Academy for health service research and health policy (AHSRHP) Annual Research Meeting - Health Service Research : from knowledge to action. Washington DC: AHSRHP, 2002.

9. Kaushal D, Jaggi T, Walls K. Pediatric medical errors: What do we know? What gap remain?. Ambul Pediatr 2004;4:73-81.

10. Leebov W, Scott G. Service quality improvement : The customer satisfaction strategy for health care. American Hospital Publisihing company, 1994.

11. Dyoyosugito A. Seluk beluk rumah sakit berbentuk perusahaan Jawatan. Jurnal MARSI 2002;8:10-23.

12. Indriantoro N, Supomo B. Metode Penelitian Bisnis. Edisi ke-1. Yogyakarta: BPFE, 2002. h.152-6.

13. Sastroasmoro S. Pemilihan subjek penelitian. Dalam : Sastroasmoro S, Ismael, penyunting. Dasar-dasar Metode Penelitian Klinis. Edisi ke-3. Jakarta : Sagung Seto, 2002. h.67-77.
14. Zeithaml, Parasuraman dan Berry L. A multi item scale for measuring consumer perceptions of service quality. Journal of retailing 1988:64;12-40.

15. Supranto J. Pengukuran tingkat kepuasan pelanggan. Jakarta: Penerbit Rineka Cipta, 2001. h.1.

16. Zaihan G. Pembuatan instrumen kepuasan pasien untuk menilai kepuasan pasien terhadap pelayanan di instalasi RJ Poliklinik spesialis anak RSU Palembang BARI. Tesis. Jakarta: Program Studi Kajian Administrasi Rumah Sakit, Program Pasca Sarjana Fakultas Kesehatan Masyarakat Universitas Indonesia, 2003.

17. Madiar N. Faktor-faktor yang berhubungan dengan kepuasan pelanggan di unit rawat jalan anak Rumah Sakit Ibu dan Anak Hermina Depok tahun 2003. Tesis. Jakarta: Program Studi Kajian Administrasi Rumah Sakit, Program Pasca Sarjana Fakultas Kesehatan Masyarakat Universitas Indonesia, 2003.

18. Sakti I. Analisis faktor-faktor yang berhubungan dengan kepuasan pasien rawat jalan di Poliklinik Anak RSUD Muara Bungo.Tesis. Jakarta : Program Studi Kajian Administrasi Rumah Sakit, Program Pasca Sarjana Fakultas Kesehatan Masyarakat Universitas Indonesia, 2001. h.14.

19. Sumampow PRV. Analisa tingkat kepuasan pasien rawat jalan Poli Anak RSAL Dr. Mintoharjo Jakarta Mei 2003. Tesis. Jakarta: Program Studi Kajian Administrasi Rumah Sakit, Program Pasca Sarjana Fakultas Ilmu Kesehatan Masyarakat Universitas Indonesia. 2003.

20. Anonim. Scottish Executive Publications. Managing Waiting Times: A Good Practice Guide. Diunduh dari http://www.scotland.gov.uk/ Publications/2003/09/ 18035/25475. Diakses pada tangggal 1 Pebruari 2006.

21. Fernandes C, Daya M, Barry S, Palmer N. Emergency department patients who leave without seeing a physician: the Toronto Hospital experience. Ann of Emer Med 1994;24:1092-6.

22. Cupit L. A systems approach to reducing waiting time in outpatient clinics. Nurs Econ 1995;4:140-5.

23. Bedi S, Arya S, Sarma RK. Patient expectation survey-a relevant marketing tool for hospital. JAHA 2004; 16(1):1-6.

24. O’Malley M, Fletcher S, Fletcher R, Earp J. Measuring patient waiting time in a practice setting: a comparison of methods. J of Amb Care Manage 1993;6: 20-7.

25. Rasidy G. Rata-rata waktu pelayanan kesehatan pasien di poliklinik umum dalam upaya peningkatan pelayanan kesehatan. Departemen Ilmu Kesehatan Anak Rumah Sakit Cipto Mangunkusumo Jakarta, 2005. 
Sari Pediatri, Vol. 8, No. 2, September 2006

26. Blender R. Are Your Patients Patiently Waiting? What to Do About Patient Waiting Times. Diunduh dari http:// www. academyconnect. uchospitals.edu/v1/library/uch_

006285.htm. Diakses pada tanggal 9 Januari 2006. 